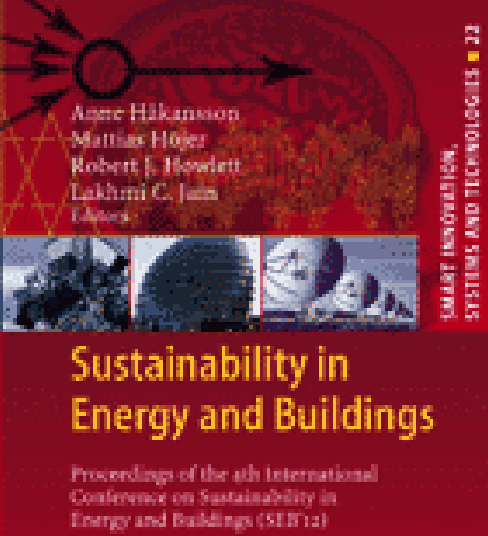




\section{Smart Innovation, Systems and Technologies}

\section{Volume 22}

\section{Series Editors}

R. J. Howlett, Shoreham-by-Sea, UK

L. C. Jain, Adelaide, Australia 
Anne Håkansson • Mattias Höjer

Robert J. Howlett • Lakhmi C. Jain

Editors

\section{Sustainability in \\ Energy and Buildings}

Proceedings of the 4th International

Conference on Sustainability in

Energy and Buildings (SEB'12)

Springer 


\section{Editors}

Professor Anne Håkansson

The Royal Institute of Technology - KTH

Kista

Sweden

Professor Mattias Höjer

Centre for Sustainable Communications

KTH Royal Institute of Technology

Stockholm

Sweden
Professor Robert J. Howlett

KES International \& Bournemouth University

United Kingdom

Professor Lakhmi C. Jain

School of Electrical and Information

Engineering

University of South Australia

South Australia

Australia
ISSN 2190-3018

ISBN 978-3-642-36644-4

Printed in 2 Volumes

DOI 10.1007/978-3-642-36645-1

Springer Heidelberg New York Dordrecht London

Library of Congress Control Number: 2013932298

(C) Springer-Verlag Berlin Heidelberg 2013

This work is subject to copyright. All rights are reserved by the Publisher, whether the whole or part of the material is concerned, specifically the rights of translation, reprinting, reuse of illustrations, recitation, broadcasting, reproduction on microfilms or in any other physical way, and transmission or information storage and retrieval, electronic adaptation, computer software, or by similar or dissimilar methodology now known or hereafter developed. Exempted from this legal reservation are brief excerpts in connection with reviews or scholarly analysis or material supplied specifically for the purpose of being entered and executed on a computer system, for exclusive use by the purchaser of the work. Duplication of this publication or parts thereof is permitted only under the provisions of the Copyright Law of the Publisher's location, in its current version, and permission for use must always be obtained from Springer. Permissions for use may be obtained through RightsLink at the Copyright Clearance Center. Violations are liable to prosecution under the respective Copyright Law.

The use of general descriptive names, registered names, trademarks, service marks, etc. in this publication does not imply, even in the absence of a specific statement, that such names are exempt from the relevant protective laws and regulations and therefore free for general use.

While the advice and information in this book are believed to be true and accurate at the date of publication, neither the authors nor the editors nor the publisher can accept any legal responsibility for any errors or omissions that may be made. The publisher makes no warranty, express or implied, with respect to the material contained herein.

Printed on acid-free paper

Springer is part of Springer Science+Business Media (www.springer.com) 


\section{Organization}

\section{Honorary Chairs}

\section{Göran Finnveden}

Björn Birgisson

and

Professor Lakhmi C. Jain
Strategic Environmental Analysis

KTH Royal Institute of Technology, Sweden

Division of Highway Engineering

KTH Royal Institute of Technology, Sweden

\section{General Chairs}

Assoc Prof. Anne Håkansson Communication Systems

KTH Royal Institute of Technology, Sweden

and

Professor Mattias Höjer Centre for Sustainable Communications

KTH Royal Institute of Technology, Sweden

\section{Executive Chair}

Professor Robert J. Howlett Executive Chair, KES International Bournemouth University, United Kingdom

\section{Program Chairs}
Ronald Hartung
Computer Sciences and Mathematics
Franklin University, Columbus, Ohio, USA 
and

Mark Smith

Communication Systems

KTH Royal Institute of Technology, Stockholm, Sweden

\section{Publicity and Support Chairs}

Bernhard Huber

Dan Wu

Nils Brown

and

\section{Esmiralda Moradian}

Faye Alexander

Shaun Lee

and

Russ Hepworth
Centre for Sustainable Communications (CESC)

KTH Royal Institute of Technology, Stockholm, and Sweden

Communication Systems

KTH Royal Institute of Technology, Stockholm, Sweden

Centre for Sustainable Communications (CESC)

KTH Royal Institute of Technology, Stockholm, Sweden

Communication Systems

KTH Royal Institute of Technology, Stockholm, Sweden

Conference Operations, KES International, UK

Information Systems Support, KES International, UK

Business Development Manager, KES International, UK

\section{Invited Sessions Chairs and Workshop}

Smart Buildings, Smart Grids

Chair: Dr Catalina Spataru

Assessment and Monitoring The Environmental Performance of Buildings Chair:Dr John Littlewood

Methodology for Renewable Energy Assessment

Chair: Dr Rainer Zah

Improving Office Building Energy Performance Chair:Dr Emeka Osaji 
Multi-Energy Sources

Chair:Prof Aziz Naamane

Technologies and Applications of Solar Energy

Chair: Prof Mahieddine Emziane

Energy Planning in Buildings and Policy Implications

Chair: Dr Eva Maleviti

Sustainable Energy Systems and Building Services

Chair:Prof Ivo Martinac

Sustainable and healthy buildings

Chair: Prof Jeong Tai Kim

Co-chair: Prof. Geun Young Yun

Special selection

Chair: Prof Robert Howlett

REQUEST Workshop

\section{Invited Keynote Speakers}

Professor Göran Finnveden KTH Royal Institute of Technology, Stockholm, Sweden

Professor Per Heiselberg Aalborg University, Denmark,

Professor Guð̋ni

A. Jóhannesson Icelandic National Energy Authority, Iceland,

Professor Lynne A. Slivovsky California Polytechnic State University, San Luis

Obispo, California, USA 


\section{International Programme Committee}

Meniai Abdeslam-Hasse

Nora Cherifa Abid

Vivek Agarwal

Abdel Aitouche

Nader Anani

Naamane Aziz

Messaouda Azzouzi

Brahim Benhamou

Frede Blaabjerg

Saadi Bougoul

Mohamed Chadli

Christopher Chao

Zhen Chen

Derek Clements-Croome

Gouri Datta

Mohamed Djemai

Philip Eames

Mahieddine Emziane

Luis Fajardo-Ruano

Antonio Gagliano

Oleg Golubchikov

Ahmed Hajjaji

Abdelaziz Hamzaoui

Sture Holmberg

Robert J. Howlett

Bin-Juine Huang

Kenneth Ip

Hong Jin

Roger Kemp

Sumathy Krishnan

Angui Li

Soren Linderoth

John Littlewood

Nacer Kouider M'Sirdi

Noureddine Manamani
Université Mentouri de Constantine, Algeria

Aix-Marseille University, France

Indian Institute of Technology Bombay, India

Lagis Hei, France

Manchester Metropolitan University, UK

Marseilles Aix Marseille Universite (AMU), France

Ziane Achour University of Djelfa, Algeria

Cadi Ayyad University of Marrakech, Morroco

Aalborg University Inst. Of Energy Technology, Denmark

Université de Batna, Algerie

University of Picardie Jules Verne, France

Hong Kong University of Science and Technology, China

Heriot-Watt University, Scotland

Reading University, UK

Deshbandhu College, Kalkaji, University of Delhi,

India and Stromstad Academy, Stromstad.

Université de Valenciennes et du Hainaut

Cambrésis, France

Loughborough University, UK

Masdar Institute of Science and Technology, Abu Dhabi

Uumsnh, Morelia, Mexico

University of Catania, Italy

University of Birmingham, UK

University of Picardie Jules Verne, France

University of Reims Champagne Ardenne, France

Royal Institute of Technology (KTH) Stockholm,

Sweden

Bournemouth University, UK

National Taiwan University, Taipei, Taiwan

University of Brighton, UK

Harbin Institute of Technology, China

Lancaster University, UK

North Dakota State University, USA

Xi' an University of Architecture \& Technology,

China

Technical University of Denmark

Cardiff Metropolitan University, UK

Laboratoire des Sciences del'Information et des Systèmes, France

University of Reims, France 


$\begin{array}{ll}\begin{array}{l}\text { Ahmed Mezrhab } \\ \text { Behdad Moghtaderi }\end{array} & \text { University Mohammed 1, Oujda Morocco } \\ \text { Roger Morgan } & \text { University of Newcastle, Australia } \\ \text { Mostafa Mrabti } & \text { Liverpool John Moores University, UK } \\ & \text { Universite Sidi Mohamed Ben Abdellah, Fes, } \\ \text { Morocco } & \text { Universidade Nova de Lisboa FCT/UNL, Portugal } \\ \text { Rui Neves-Silva } & \text { University of Wolverhampton, UK } \\ \text { Emeka Efe Osaji } & \text { University of Genova, Italy } \\ \text { Frederici Pittaluga } & \text { University of Glamorgan, UK } \\ \text { Giuliano C Premier } & \text { MIS Amiens, France } \\ \text { Abdelhamid Rabhi } & \text { University of Picardie Jules Verne, France } \\ \text { Ahmed Rachid } & \text { University IUAV of Venice, Italy } \\ \text { Enzo Siviero } & \text { Malaviya National Institute of Technology, Jaipur, } \\ \text { Shyam Lal Soni } & \text { India } \\ \text { Catalina Spataru } & \text { UCL Energy Institute, Uk } \\ \text { Alessandro Stocco } & \text { University of Nova Gorica and partner Progeest } \\ & \text { S.r.l. of Padua, Italy } \\ \text { Lounes Tadrist } & \text { Polytech.univ-mrs, France } \\ \text { Dario Trabucco } & \text { IUAV University of Venice, Italy } \\ \text { Mummadi Veerachary } & \text { Indian Institute of Technology, Delhi, India } \\ \text { Wim Zeiler } & \text { TU Eindhoven, Faculty of the Built Environment, } \\ & \text { Netherlands } \\ \text { Mohcine Zouak } & \text { USMBA FST, Morocco } \\ \text { Rainer Zah } & \text { Life Cycle Assessment \& Modelling Group, Empa, } \\ & \text { Switzerland }\end{array}$

\section{Keynote Speakers}

We are very pleased to have acquired the services of an excellent selection of keynote speakers for SEB'12. These speakers gave a view about technological and scientific activities, relating to sustainability in energy and buildings, taking place in various areas of the world.

\section{Professor Göran Finnveden}

KTH Royal Institute of Technology, Sweden

\section{Sustainability Challenges for the Building Sector}

\section{Abstract:}

The building and real estate management sector is responsible for a significant part of the environmental impacts of our society. The sector's contribution to the threat of climate change for production of heat and electricity for the buildings are of special importance. It is important to consider the full life-cycle of buildings and also consider 
production and transportation of building materials, construction and waste management. In Sweden, emissions of gases contributing to climate change from heating of buildings have decreased during the last decades as results of strong policy instruments. One the other hand emissions from other parts of the life-cycle of buildings have increased, illustrating the need to have a wide systems perspective in order to avoid suboptimizations. It is also important to consider other environmental threats such as the use of hazardous chemicals, air quality, generation of waste and impacts on ecosystems from production of building materials as well as on building sites.

The building sector has a large potential to reduce its environmental footprint. Many of the most cost-efficient possibilities for mitigation of climate change are related to the building sector. Governmental policies are important for changes to be made. Voluntary instruments such as building rating tools may have an additional role. The ICT-sector may have one of its largest potentials in contributing to a more sustainable society in the building sector. Because of the long life-time of buildings, we are now constructing the future environmental impacts. When looking for cost-efficient solutions, we must therefore also consider the future cost-efficiency. In the presentation also social aspects of sustainability will be discussed including possibilities for the building sector to contribute to a better health and reduced health inequalities.

\section{Biography:}

Göran Finnveden is Professor in Environmental Strategic Analysis and Vice-President for sustainable development at KTH Royal Institute of Technology, Stockholm, Sweden. He is a M.Sc. in Chemical Engineering 1989, PhD in Natural Resources Management, Associate Professor in Industrial Ecology 2003 and full Professor 2007. His research has focused on environmental systems analysis tools such as Life Cycle Assessment, Strategic Environmental Assessment and Input-Output Analysis. It has included both methodological development and case studies. Application areas include buildings, energy systems, information and communication technologies, infrastructure and waste management. He has also worked with environmental policy in areas such as environmental policy integration, integrated product policy and waste policy. He is a currently a member of the Scientific Advisory Council to the Swedish Minister of the Environment, an expert in the governmental commission on waste management and a member of the board of directors of the Swedish Waste Nuclear Fund. According to Scopus he has published more than 60 scientific papers and is cited nearly 2000 times.

\section{Professor Per Heiselberg}

Aalborg University, Denmark

\section{Buildings - both part of the problem and the solution!}




\section{Abstract:}

Energy use for room heating, cooling and ventilation accounts for more than one-third of the total, primary energy demand in the industrialized countries, and is in this way a major polluter of the environment. At the same time the building sector is identified as providing the largest potential for $\mathrm{CO} 2$ reduction in the future and many countries across the world have set very ambitious targets for energy efficiency improvements in new and existing buildings. For example at European level the short term goal has recently been expressed in the recast of the EU Building Performance Directive as "near zero energy buildings" by 2020.

To successfully achieve such a target it is necessary to identify and develop innovative integrated building and energy technologies, which facilitates considerable energy savings and the implementation and integration of renewable energy devices within the built environment. The rapid development in materials science, information and sensor technology offers at the same time considerable opportunities for development of new intelligent building components and systems with multiple functions.

Such a development will impose major challenges on the building industry as building design will completely change from design of individual components and systems to integrated design of systems and concepts involving design teams of both architects, engineers and other experts. Future system and concepts solutions will require that building components must be able fulfill multiple performance criteria and often contradictory requirements from aesthetics, durability, energy use, health and comfort. A key example of this is building facades that instead of the existing static performance characteristics must develop into dynamic solutions with the ability to dynamically adjust physical properties and energetic performance in response to fluctuations in the outdoor environment and changing needs of the occupants in order to fulfill the future targets for energy use and comfort. Buildings will also be both consumers and producers of energy, which creates a number of new challenges for building design like identification of the optimum balance between energy savings and renewable energy production. The interaction between the energy "prosuming" building and the energy supply grid will also be an important issue to solve.

The lecture will address and illustrate these future challenges for the building sector and give directions for solutions.

\section{Biography:}

Per Heiselberg is Professor at the Department of Civil Engineering at Aalborg University, Denmark. He holds a M.Sc. and a Ph.D. in Indoor Environmental Engineering. His research and teaching subjects are within architectural engineering and are focused on the following topics:

- Energy-efficient building design (Net zero energy buildings, design of low energy buildings - integration of architectural and technical issues, modelling of double skin facades, night cooling of buildings and utilization of thermal mass, multifunctional facades, daylight in buildings, passive energy technologies for buildings, modeling of building energy use and indoor environment) 
- Ventilation and air flow in buildings (Modelling and measurements of air and contaminants flows (both gas- and particles) in buildings, ventilation effectiveness, efficient ventilation of large enclosures, numerical simulation (computational fluid dynamics) of air and contaminant flows as well as modeling of natural and hybrid ventilation)

Per Heiselberg has published about 300 articles and papers on these subjects.

Currently, Per Heiselberg is leading the national strategic research centre on Net Zero Energy Buildings in Denmark (www.zeb.aau.dk). The centre has a multidisciplinary research approach and a close cooperation with leading Danish companies. He has been involved in many EU and IEA research projects in the past 20 years. He was the operating agent of IEA-ECBCS Annex 35 (1997-2002) and IEA-ECBCS Annex 44 (20052009), (www.ecbcs.org). Presently he is involved in ECBCS Annexes 52, 53 and 59.

\section{Professor Guỡni A. Jóhannesson}

Icelandic National Energy Authority, Iceland

\section{Meeting the challenges of climatic change - the hard way or the clever way}

\section{Abstract:}

We may not agree on how the possible $\mathrm{CO} 2$ driven scenarios of climate change in the future may look like but we all can agree that the anthropogenic increase in $\mathrm{CO} 2$ levels in the world atmosphere exposes humanity to higher risks of changes in the environment than we want to face in our, our children's or their children's lifetime.

It is evident that we are now facing a global challenge that we are more often dealing with by local solutions. Our guiding rule is that by saving energy we are also mitigating greenhouse gas emission. Also if we are using renewable energy and substituting fossil fuels we are also moving in the right direction. There are however important system aspects that we should be considering.

The first one if we are using the right quality of energy for the right purpose. A common example is when high quality energy such as electricity or gas is used directly to provide domestic hot water or heat houses instead of using heat pumps or cogeneration processes to get the highest possible ratio between the used energy and the primary energy input.

The second one is if we are obstructing necessary structural changes that could lead to a more effective energy system globally. We have big reserves of cost effective renewable energy sources, hydropower and geothermal energy around the world that are far from the markets and would therefore need relocation structural changes in our industrial production system to be utilized.

The third aspect is if we are using our investments in energy conversion and energy savings in the best way to meet our climatic goals or if we are directed by other hidden agendas to such a degree that a large part of our economical input is wasted.

It is evident that the national and local strategies for energy savings are closely linked to other strategic areas such as industrial development, household economy, mobility. 
Also a necessary precondition for investment is that the nations maintain their economic strength and their ability to develop their renewable resources and to invest in new more efficient processes.

The key to success in mitigating the climatic change is therefor to create a holistic strategy that beside the development of technical solutions for energy efficiency and utilization of renewable energy also considers the local and global system aspects. With present technologies for energy efficient solutions, proper energy quality management $r$ and with utilization of cost effective renewable energy sources we have all possibilities to reduce energy related the global $\mathrm{CO} 2$ emissions to acceptable levels.

\section{Biography:}

Professor Guð̋ni A. Jóhannesson is born in Reykjavik 1951. He finished his MSc in Engineering physics in 1976, his PhD thesis on thermal models for buildings in 1981 and was appointed as an associate professor at Lund University in 1982. He was awarded the title of doctor honoris causae from the University of Debrecen in 2008 and the Swedish Concrete Award in 2011. From 1975 he worked as a research assistant at Lund University, from 1982 as a consultant in research and building physics in Reykjavik and from 1990 as a professor in Building Technology at KTH in Stockholm and from 2008 an affiliated professor at KTH. His research has mainly concerned the thermodynamical studies of buildings, innovative building systems and energy conservation in the built environment. Since the beginning of 2008 he is the Director General of the Icelandic National Energy Authority which is responsible for public administration of energy research, energy utilization and regulation. He was a member of the The Hydropower Sustainability Assessment Forum processing the Hydropower Sustainability Assessment Protocol adopted by IHA in November 2010 and presently the chair of IPGT the International Partnership for Geothermal Technologies.

\section{Professor Lynne A. Slivovsky}

California Polytechnic State University, USA

\section{The Questions That Keep Me Up At Night}

\section{Abstract:}

This keynote will provide an opportunity for reflection on the work we do. We're here talking about energy and sustainability but we're also talking about a different way of living. We, as a technical field, a society, a world, are on a path of profound technological development. What does it mean to educate someone to contribute to this world? To have a technical education? What does it mean to live in this world? And is it possible that we as designers, innovators, engineers, and scientists can consider these questions in our day-to-day work? 
Biography:

Lynne A. Slivovsky (Ph.D., Purdue University, 2001) is Associate Professor of Electrical and Computer Engineering at California Polytechnic State University, San Luis Obispo, California, USA. In 2003 she received the Frontiers In Education New Faculty Fellow Award. Her work in service-learning led to her selection in 2007 as a California Campus Compact-Carnegie Foundation for the Advancement of Teaching Faculty Fellow for Service-Learning for Political Engagement. In 2010 she received the Cal Poly President's Community Service Award for Significant Faculty Contribution. She currently oversees two multidisciplinary service-learning programs: the Access by Design Project that has capstone students designing recreational devices for people with disabilities and the Organic Twittering Project that merges social media with sustainability. Her work examines design learning in the context of engagement and the interdependence between technology and society.

Panel: Sustainability: Current and Future with focus on Energy, Buildings and ICT

Panel:

Sofia Ahlroth, Working Party on Integrating Environmental and Economic Policies (WPIEEP), Swedish EPA

Magnus Enell, Senior Advisor Sustainability at Vattenfall AB, Sweden

Göran Finnveden, Professor, KTH Royal Institute of Technology, Sweden

Danielle Freilich, Environmental expert at The Swedish Construction Federation (BI), Sweden

Catherine.Karagianni, Manager for Environmental and Sustainable Development at Teliasonera, Sweden

Örjan Lönngren, Climate and energy expert, Environment and Health Department, City of Stockholm, Sweden

Per Sahlin, Simulation entrepreneur, Owner of EQUA Simulation AB, Sweden

Mark Smith, Professor, KTH Royal Institute of Technology, Sweden

Örjan Svane, Professor, KTH Royal Institute of Technology, Sweden

Olle Zetterberg, CEO, Stockholm Business Region, Stockholm, Sweden 


\section{Contents}

\section{Volume 1}

\section{Session: Sustainability in Energy and Buildings}

1 Transformational Role of Lochiel Park Green Village .............. . 1 Stephen Robert Berry

2 Evaluation and Validation of an Electrical Model of Photovoltaic Module Based on Manufacturer Measurement ................ 15 Giuseppe M. Tina, Cristina Ventura

3 Evolution of Environmental Sustainability for Timber and Steel Construction

Dimitrios N. Kaziolas, Iordanis Zygomalas, Georgios E. Stavroulakis, Dimitrios Emmanouloudis,

Charalambos C. Baniotopoulos

4 Using the Energy Signature Method to Estimate the Effective U-Value of Buildings

Gustav Nordström, Helena Johnsson, Sofia Lidelöw

5 Two Case Studies in Energy Efficient Renovation of Multi-family Housing; Explaining Robustness as a Characteristic to Assess Long-Term Sustainability . .

Vahid Sabouri, Paula Femenías

6 Exploring the Courtyard Microclimate through an Example of Anatolian Seljuk Architecture: The Thirteenth-Century Sahabiye Madrassa in Kayseri . . . . . . . . . . . . . . . . . . . . . . .

Hakan Hisarligil 
7 Analysis of Structural Changes of the Load Profiles of the German Residential Sector due to Decentralized Electricity Generation and

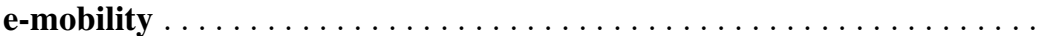

Rainer Elsland, Tobias Boßmann, Rupert Hartel, Till Gnann, Massimo Genoese, Martin Wietschel

8 The Impact of Hedonism on Domestic Hot Water Energy Demand for Showering - The Case of the Schanzenfest, Hamburg . . . . . . . . .

Stephen Lorimer, Marianne Jang, Korinna Thielen

9 The Process of Delivery - A Case Study Evaluation of Residential Handover Procedures in Sustainable Housing . . . . . . . . . . . . . . 95 David Bailey, Mark Gillott, Robin Wilson

10 Sustainable Renovation and Operation of Family Houses for Improved Climate Efficiency . . . . . . . . . . . . . . . . . . . . . . . . . . . . . . 107 Ricardo Ramírez Villegas, Björn Frostell

11 Solar Collector Based on Heat Pipes for Building Façades

Rassamakin Boris, Khairnasov Sergii, Musiy Rostyslav, Alforova Olga, Rassamakin Andrii

12 ICT Applications to Lower Energy Usage in the Already Built Environment

Anna Kramers

13 Using Dynamic Programming Optimization to Maintain Comfort in Building during Summer Periods

Bérenger Favre, Bruno Peuportier

14 Assisting Inhabitants of Residential Homes with Management of their Energy Consumption . . . . . . . . . . . . . . . . . . . . . . . . . . . . . . 147 Michael Kugler, Elisabeth André, Masood Masoodian, Florian Reinhart, Bill Rogers, Kevin Schlieper

15 Raising High Energy Performance Glass Block from Waste Glasses with Cavity and Interlayer . . . . . . . . . . . . . . . . . . . . . . . 157 Floriberta Binarti, Agustinus D. Istiadji, Prasasto Satwiko, Priyo T. Iswanto

16 A New Model for Appropriate Selection of Window . . . . . . . . . . . . . . . . . 167 Abdolsalam Ebrahimpour, Yousef Karimi Vahed

17 Improved Real Time Amorphous PV Model for Fault Diagnostic Usage

Mehrdad Davarifar, Abdelhamid Rabhi, Ahmed EL Hajjaji, Jerome Bosche, Xavier Pierre 
18 An Investigation of Energy Efficient and Sustainable Heating Systems for Buildings: Combining Photovoltaics with Heat Pump . . . . 189 Arefeh Hesaraki, Sture Holmberg

19 Assessment of Solar Radiation Potential for Different Cities in Iran

Using a Temperature-Based Method .

Farivar Fazelpour, Majid Vafaeipour, Omid Rahbari,

Mohammad H. Valizadeh

20 A Decision Support Framework for Evaluation of Environmentally and Economically Optimal Retrofit of Non-domestic Buildings . . . . . 209 Taofeeq Ibn-Mohammed, Rick Greenough, Simon Taylor, Leticia Ozawa-Meida, Adolf Acquaye

21 Modeling, From the Energy Viewpoint, a Free-Form, High Energy Performance, Transparent Envelope.

Luis Alonso, C. Bedoya, Benito Lauret, Fernando Alonso

22 A Mathematical Model to Pre-evaluate Thermal Efficiencies in Elongated Building Designs

Alberto Jose Fernández de Trocóniz y Revuelta,

Miguel Ángel Gálvez Huerta,

Alberto Xabier Fernández de Trocóniz y Rueda

23 Effect of Reaction Conditions on the Catalytic Performance of Ruthenium Supported Alumina Catalyst for Fischer-Tropsch

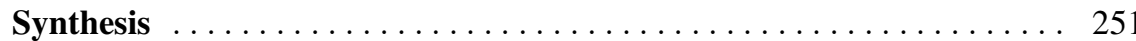

Piyapong Hunpinyo, Phavanee Narataruksa, Karn Pana-Suppamassadu, Sabaithip Tungkamani, Nuwong Chollacoop, Hussanai Sukkathanyawat

24 Integration of Wind Power and Hydrogen Hybrid Electric Vehicles into Electric Grids

Stephen J.W. Carr, Kary K.T. Thanapalan, Fan Zhang, Alan J. Guwy, J. Maddy, Lars-O. Gusig, Giuliano C. Premier

25 Analysis of Thermal Comfort and Space Heating Strategy: Case Study in an Irish Public Building

Oliver Kinnane, M. Dyer, C. Treacy

26 Protection of Ring Distribution Networks with Distributed

Generation Based on Petri Nets

Haidar Samet, Mohsen Khorasany

27 Real-Time Optimization of Shared Resource Renewable Energy

Networks

Stephen Treado, Kevin Carbonnier 
28 Evaluation of the LCA Approaches for the Assessment of Embodied Energy of Building Products Ayşen Ciravoğlu and Gökçe Tuna Taygun

29 Exergetic Life Cycle Assessment: An Improved Option to Analyze Resource Use Efficiency of the Construction Sector

Mohammad Rashedul Hoque, Xavier Gabarrell Durany,

Gara Villalba Méndez, Cristina Sendra Sala

30 Methodology for the Preparation of the Standard Model for Schools Investigator for the Sustainability of Energy Systems and Building Services .

Hisham ElShimy

31 Latin-American Buildings Energy Efficiency Policy: The Case of Chile

Massimo Palme, Leônidas Albano, Helena Coch, Antoni Isalgué, José Guerra

32 Thermal Performance of Brazilian Modern Houses: A Vision through the Time

Leônidas Albano, Marta Romero, Alberto Hernandez Neto

\section{Short Papers}

33 Energetic and Exergetic Performance Evaluation of an $\mathrm{AC}$ and a Solar Powered DC Compressor

Orhan Ekren, Serdar Çelik

34 Effectiveness of Sustainable Assessment Methods in Achieving High Indoor Air Quality in the UK

Gráinne McGill, Menghao Qin, Lukumon Oyedele

35 A Comprehensive Monitoring System to Assess the Performance of a Prototype House

Oliver Kinnane, Tom Grey, Mark Dyer

\section{Session: Smart Buildings, Smart Grids}

Invited Sessions

36 Smart Consumers, Smart Controls, Smart Grid

Catalina Spataru, Mark Barrett

37 A Qualitative Comparison of Unobtrusive Domestic Occupancy Measurement Technologies

Eldar Nagijew, Mark Gillott, Robin Wilson 
38 Review of Methods to Map People's Daily Activity - Application for Smart Homes . . . . . . . . . . . . . . . . . . . . . . . 401 Stephanie Gauthier, David Shipworth

39 Optimizing Building Energy Systems and Controls for Energy and Environment Policy . . . . . . . . . . . . . . . . . . . . 413 Mark Barrett, Catalina Spataru

40 Towards a Self-managing Tool for Optimizing Energy Usage in Buildings

Naveed Arshad, Fahad Javed, Muhammad Dawood Liaqat

41 A Library of Energy Efficiency Functions for Home Appliances. Hamid Abdi, Michael Fielding, James Mullins, Saeid Nahavandi

42 Smart Energy Façade for Building Comfort to Optimize Interaction with the Smart Grid

Wim Zeiler, Rinus van Houten, Gert Boxem, Joep van der Velden

43 Building for Future Climate Resilience: A Comparative Study of the Thermal Performance of Eight Constructive Methods . . . . . . . . . . . . 453 Lucelia Rodrigues, Mark Gillott

\section{Session: Assessment and Monitoring the Environmental Performance of Buildings}

44 Exploring Indoor Climate and Comfort Effects in Refurbished Multi-family Dwellings with Improved Energy Performance

Linn Liu, Josefin Thoresson

45 Occupancy-Driven Supervisory Control Strategies to Minimise

Energy Consumption of Airport Terminal Building .

D. Abdulhameed Mambo, Mahroo Efthekhari, Thomas Steffen

46 An Investigation into the Practical Application of Residential Energy Certificates ............................... 491 Alan Abela, Mike Hoxley, Paddy McGrath, Steve Goodhew

47 Post-Occupancy Evaluation of a Mixed-Use Academic Office Building

Katharine Wall, Andy Shea

48 The Human as Key Element in the Assessment and Monitoring of the Environmental Performance of Buildings

Wim Zeiler, Rik Maaijen, Gert Boxem

49 The Effects of Weather Conditions on Domestic Ground-Source Heat Pump Performance in the UK Anne Stafford 
50 Asset and Operational Energy Performance Rating of a Modern Apartment in Malta

Charles Yousif, Raquel Mucientes Diez, Francisco Javier Rey Martínez

51 Low Carbon Housing: Understanding Occupant Guidance and Training

Isabel Carmona-Andreu, Fionn Stevenson, Mary Hancock

\section{Volume 2}

52 Embodied Energy as an Indicator for Environmental Impacts A Case Study for Fire Sprinkler Systems 555

Tom Penny, Michael Collins, Simon Aumônier, Kay Ramchurn, Terry Thiele

53 Understanding the Gap between as Designed and as Built Performance of a New Low Carbon Housing Development in UK . . . . 567 Rajat Gupta, Dimitra Dantsiou

54 Preliminary Evaluation of Design and Construction Details to Maximize Health and Well-Being in a New Built Public School in Wroclaw

Magdalena Baborska-Narozny, Anna Bac

55 Comparison of Design Intentions and Construction Solutions Delivered to Enhance Environmental Performance and Minimize Carbon Emissions of a New Public School in Wroclaw

Magdalena Baborska-Narozny, Anna Bac

56 An Exploration of Design Alternatives Using Dynamic Thermal Modelling Software of an Exemplar, Affordable, Low Carbon Residential Development Constructed by a Registered Social Landlord in a Rural Area of Wales

Simon Hatherley, Wesley Cole, John Counsell, Andrew Geens, John Littlewood, Nigel Sinnett

57 Basic Energy and Global Warming Potential Calculations at an Early Stage in the Development of Residential Properties

Nils Brown

58 Passive Cooling Strategies for Multi-storey Residential Buildings in Tehran, Iran and Swansea, UK

Masoudeh Nooraei, John Littlewood, Nick Evans

59 An (un)attainable Map of Sustainable Urban Regeneration

Linda Toledo, John R. Littlewood 
Session: Methodology for Renewable Energy Assessment

60 LCA in The Netherlands: A Case Study . . . . . . . . . . . . . . . . . . . . . 649 Wim Zeiler, Ruben Pelzer, Wim Maassen

61 Comparative Life-Cycle Assessment of Residential Heating Systems, Focused on Solid Oxide Fuel Cells Alba Cánovas, Rainer Zah, Santiago Gassó

\section{Session: Improving Office Building Energy Performance}

62 A Sustainable Energy Saving Method for Hotels by Green Hotel Deals

Hamid Abdi, Doug Creighton, Saeid Nahavandi

63 The Role of Building Energy and Environmental Assessment in Facilitating Office Building Energy-Efficiency

Emeka E. Osaji, Subashini Suresh, Ezekiel Chinyio

64 Improved Personalized Comfort: A Necessity for a Smart Building . . . 705 Wim Zeiler, Gert Boxem, Derek Vissers

65 Reducing Ventilation Energy Demand by Using Air-to-Earth Heat Exchangers: Part 1 - Parametric Study

Hans Havtun, Caroline Törnqvist

66 Reducing Ventilation Energy Demand by Using Air-to-Earth Heat Exchangers: Part 2 System Design Considerations

Hans Havtun, Caroline Törnqvist

67 The Green Room: A Giant Leap in Development of Energy-Efficient Cooling Solutions for Datacenters

Hans Havtun, Roozbeh Izadi, Charles El Azzi

68 The Impacts of Contributory Factors in the Gap between Predicted and Actual Office Building Energy Use

Emeka E. Osaji, Subashini Suresh, Ezekiel Chinyio

\section{Session: Multi-Energy Sources}

69 Improving Multiple Source Power Management Using State Flow Approach

Aziz Naamane, Nacer Msirdi

70 Technical-Economic Analysis of Solar Water Heating Systems at Batna in Algeria. 
71 Design and Control of a Diode Clamped Multilevel Wind Energy System Using a Stand-Alone AC-DC-AC Converter . . . . . . . . . . . . . 797 Mona F. Moussa, Yasser G. Dessouky

\section{Session: Technologies and Applications of Solar Energy}

72 Analyzing the Optical Performance of Intelligent Thin Films Applied to Architectural Glazing and Solar Collectors . . . . . . . . . . . . . . 813 Masoud Kamalisarvestani, Saad Mekhilef, Rahman Saidur

73 A Sunspot Model for Energy Efficiency in Buildings . . . . . . . . . . 827 Yosr Boukhris, Leila Gharbi, Nadia Ghrab-Morcos

74 Towards 24/7 Solar Energy Utilization: The Masdar Institute Campus as a Case Study

Mona Aal Ali, Mahieddine Emziane

75 Effect of Selective Emitter Temperature on the Performance of Thermophotovoltaic Devices

Mahieddine Emziane, Yao-Tsung Hsieh

76 New Tandem Device Designs for Various Photovoltaic Applications . . . 859 Mahieddine Emziane

77 GIS-Based Decision Support for Solar Photovoltaic Planning in Urban Environment

Antonio Gagliano, Francesco Patania, Francesco Nocera, Alfonso Capizzi, Aldo Galesi

78 Infrared Thermography Study of the Temperature Effect on the Performance of Photovoltaic Cells and Panels

Zaoui Fares, Mohamed Becherif, Mahieddine Emziane, Abdennacer Aboubou, Soufiane Mebarek Azzem

79 Integrating Solar Heating and PV Cooling into the Building Envelope .

Sleiman Farah, Wasim Saman, Martin Belusko

\section{Session: Energy Planning in Buildings and Policy Implications}

80 Risk and Uncertainty in Sustainable Building Performance . . . . . . . . 903 Seyed Masoud Sajjadian, John Lewis, Stephen Sharples

81 Potential Savings in Buildings Using Stand-Alone PV Systems . . . . . . . 913 Eva Malevit, Christos Tsitsiriggos 


\section{Session: Sustainable Energy Systems and Building Services}

82 The Application of LCCA toward Industrialized Building

Retrofitting - Case Studies of Swedish Residential Building Stock . . . . 931

Qian Wang, Ivo Martinac

83 A Proposal of Urban District Carbon Budgets for Sustainable Urban

Development Projects . . . . . . . . . . . . . . . . . . . . . . . . . . . 947

Aumnad Phdungsilp, Ivo Martinac

84 A Study of the Design Criteria Affecting Energy Demand in New

Building Clusters Using Fuzzy AHP . . . . . . . . . . . . . . . . . . 955

Hai Lu, Aumnad Phdungsilp, Ivo Martinac

85 Cooling Coil Design Improvement for HVAC Energy Savings and

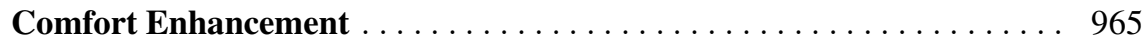

Vahid Vakiloroaya, Jafar Madadnia

86 Sustainable Integration of Renewable Energy Systems in a

Mediterranean Island: A Case Study . . . . . . . . . . . . . . . . . . . . . 975

Domenico Costantino, Mariano Giuseppe Ippolito,

Raffaella Riva_Sanseverino, Eleonora Riva_Sanseverino,

Valentina Vaccaro

\section{Session: Sustainable and Healthy Buildings}

87 Mobile Motion Sensor-Based Human Activity Recognition and Energy Expenditure Estimation in Building Environments . . . . . . . . . 987

Tae-Seong Kim, Jin-Ho Cho, Jeong Tai Kim

88 Cost and $\mathrm{CO}_{2}$ Analysis of Composite Precast Concrete Columns . . . . . 995 Keun Ho Kim, Chaeyeon Lim, Youngju Na, Jeong Tai Kim, Sunkuk Kim

89 A Field Survey of Thermal Comfort in Office Building with a Unitary Heat-Pump and Energy Recovery Ventilator

Seon Ho Jo, Jeong Tai Kim, Geun Young Yun

90 An Analysis of Standby Power Consumption of Single-Member

Huseholds in Korea .

JiSun Lee, Hyunsoo Lee, JiYea Jung, SungHee Lee, SungJun Park,

YeunSook Lee, JeongTai Kim

91 A Classification of Real Sky Conditions for Yongin, Korea

Hyo Joo Kong, Jeong Tai Kim

92 Influence of Application of Sorptive Building Materials on Decrease in Indoor Toluene Concentration 1033

Seonghyun Park, Jeong Tai Kim, Janghoo Seo 
93 Perceived Experiences on Comfort and Health in Two Apartment Complexes with Different Service Life .

Mi Jeong Kim, Myung Eun Cho, Jeong Tai Kim

94 Impact of Different Placements of Shading Device on Building Thermal Performance

Hong Soo Lim, Jeong Tai Kim, Gon Kim

95 Daylighting and Thermal Performance of Venetian Blinds in an Apartment Living Room

Ju Young Shin, Yoon Jeong Kim, Jeong Tai Kim

96 Environmentally-Friendly Apartment Buildings Using a Sustainable Hybrid Precast Composite System . . . . . . . . . . . . . . . . . . . . 1071 Ji-Hun Kim, Won-Kee Hong, Seon-Chee Park, Hyo-Jin Ko, Jeong Tai Kim

97 A System for Energy Saving in Commercial and Organizational Buildings

Hamid Abdi, Michael Fielding, James Mullins, Saeid Nahavandi

\section{Session: Special Selection}

98 A Comparative Analysis of Embodied and Operational $\mathrm{CO}_{2}$ Emissions from the External Wall of a Reconstructed Bosphorus Mansion in Istanbul

Fatih Yazicioglu, Hülya Kus 


\title{
Chapter 15 \\ Raising High Energy Performance Glass Block from Waste Glasses with Cavity and Interlayer
}

\author{
Floriberta Binarti ${ }^{1}$, Agustinus D. Istiadji ${ }^{1}$, Prasasto Satwiko ${ }^{1}$, and Priyo T. Iswanto ${ }^{2}$ \\ ${ }^{1}$ Architecture Department, University of Atma Jaya Yogyakarta, Indonesia \\ flo.binarti@gmail.com \\ ${ }^{2}$ Mechanical Engineering Department, Gadjah Mada University, Indonesia
}

\begin{abstract}
The main glazing energy performance measure in warm humid climates is light-to-solar-gain ratio (LSG), which denotes the ratio of the visible light transmittance (VT) and its solar heat gain coefficient (SHGC). In laminated glazing the LSG depends on the design of the cavity and (inter)layers. This study explored the contribution of cavity and interlayer in raising high energy performance glass block from laminated waste glasses. Analytical method and computational simulations using comparative method and heat balance model were employed to obtain glass block model with the most optimum combination of the VT, the SHGC and its thermal transmittance (U). The effect of cavity on increasing the VT was showed by simulation and laboratory test results. Based on SHGC laboratory tests, the presence of interlayer declined 69$89 \%$ of the simulated SHGC. Laminated glass block with certain number of closed cavity and interlayer can raise 4.35 of the LSG.
\end{abstract}

Keywords: cavity, glass block, interlayer, light-to-solar-gain ratio, solar heat gain coefficient, visible light transmittance.

\section{$1 \quad$ Introduction}

Building energy consumption can be reduced by adopting high energy performance glazing. In warm humid climates high energy performance glazing should have high ratio of the visible light transmittance (VT) and its solar heat gain coefficient (SHGC), which is called as Light-to-Solar-Gain Ratio (LSG). Thermal transmittance (U) is important for air conditioned buildings. Low-U building envelope can reduce the conductive heat transfer rate, which further cuts down the building cooling load. According to Energy Conservation Code 2006 vertical fenestration in warm humid climates is recommended to have 0.25 for the maximum SHGC and $3.177 \mathrm{~W} / \mathrm{m}^{2} . \mathrm{K}$ for the maximum $\mathrm{U}$ with 0.27 of the minimum VT for small fenestration area [1].

Lamination is the selected method to produce new glass block from waste glasses. This low-technology method potentially creates low U and low SHGC material. The SHGC, the VT, the U and the mechanical strength of the layers bonding depend on the layer number, the interlayer and lamination technique. Chen and Meng [2] studied 
the contribution of interlayer by examining the effect of polyvinyl butyral (PVB) laminated glass application on the building cooling load. The simulation results showed that application of $7 \mathrm{~mm}$ PVB laminated glass created lowest cooling load compared to the application $12 \mathrm{~mm}$ clear glass and $6 \mathrm{~mm}$ low-e coated glass.

Cavity was introduced in glass block as thermal resistance. Heat transfer across the cavity depends on the cavity number, dimension, the optical and the thermal properties of the material [3-6]. Cavity avoids significant reduction of the VT due to the transparency for visible light. Material with higher refractive index (RI) is less transparent. Air has 1 for the RI, whereas ordinary clear glass has 1.52.

This study explored the contribution of cavity and interlayer in raising high energy performance by obtaining and testing optimum combination of the layer number, the cavity type, number, width and position. Analytical and computational simulation approaches were used to design glass blocks with proper cavities. Contribution of the interlayer would be examined in laboratory tests.

\section{Methods}

This study employed several methods that will be explained chronologically. The first step is interlayer selection. Some criteria in selecting interlayer are transparency, emissivity, thermal conductivity, compressive and tensile strength, durability, curing time and price. Clear epoxy resin was selected as the interlayer material. Epoxy resin can form extremely strong durable bonds with glass $(50 \mathrm{MPa})$. Generally epoxy resin has $0.02-0.1 \mathrm{~W} / \mathrm{m} . \mathrm{K}$ for the thermal conductivity and 0.8 for the emissivity. The maximum RI is 1.57 .

Cavity inside glass block can be designed as open cavity and closed cavity. In this study cavity type was examined as $1 \mathrm{~m}^{2}$ vertical fenestration in a $3 \mathrm{~m}$ x $3 \mathrm{~m}$ x $3 \mathrm{~m}$ adiabatic building system using a Computational Fluid Dynamic (CFD) - ACE software package. The accuracy of simulation results of CFD - ACE has been remarkable. Validation conducted by Satwiko et al. [7] described that the air flow analysis are close to the field measurements with deviation from 0.003 until 0.027 for three dimensions with standard k- $\varepsilon$ turbulent model. In CFD - ACE geometry and mesh were created in CFD-GEOM. Models were constructed from 285,345 unstructured cell number. Simulations were conducted with steady state laminar model with low air velocity $(0.2 \mathrm{~m} / \mathrm{s})$. This condition was reached after 200 iterations and 0.0001 for the convergence. Heat flux was set to $540 \mathrm{~W} / \mathrm{m}^{2}$ (at the peak local condition). The exterior surface temperature was set to $50{ }^{0} \mathrm{C}$, whereas the interior surface temperature was set to $26.85^{\circ} \mathrm{C}$, which represents the lowest average temperature to describe significant effect of the convective heat transfer across each model.

The next step is development of glass block models with selected cavity type. Formula (1) was employed to estimate the U of each model.

$$
U=1 /\left[\left(1 / f_{0}\right)+\left(b_{1} / k_{1}\right)+\left(b_{2} / k_{2}\right)+\left(b_{1} / k_{1}\right)+R+\left(b_{1} / k_{1}\right)+\left(b_{2} / k_{2}\right)+\left(b_{1} / k_{1}\right)+\left(1 / f_{i}\right)\right]
$$

The accuracy of the formula depends on the determination of the external surface conductance in $\mathrm{W} / \mathrm{m}^{2} . \mathrm{K}\left(f_{0}\right)$, the internal surface conductance in $\mathrm{W} / \mathrm{m}^{2} . \mathrm{K}\left(f_{i}\right)$, the 
thermal resistance of cavity in $\mathrm{m}^{2} . \mathrm{K} / \mathrm{W}(R)$, the glass conductivity in $\mathrm{W} / \mathrm{m} . \mathrm{K}\left(k_{l}\right)$ and the interlayer conductivity in W/m.K $\left(k_{2}\right)$. $b$ denotes the layer thickness in $\mathrm{m}$ '. Variation in $R$ depends on the cavity width. Only interlayers among the layers were calculated.

The effects of heat transfer through each model on the airflow rate inside the cavity, the external and the internal surface temperature were simulated by CFD individually. To lighten the central processing unit (CPU) burden, interlayer in each model was neglected. This is also valid for other simulations.

The VT of glass block models was estimated using comparative method of illumination levels simulated by Radiance (plug in Ecotect). Accuracy of the simulation results rely on the models, ray tracing method $[8,9]$, and simulation setting. Models were constructed to simulate field measurement of the VT with reference to the simulation procedures developed by Laouadi and Arsenault [10]. Each glass block in the VT simulation was installed as a top lighting of a black box with zero reflectance (Fig. 1).

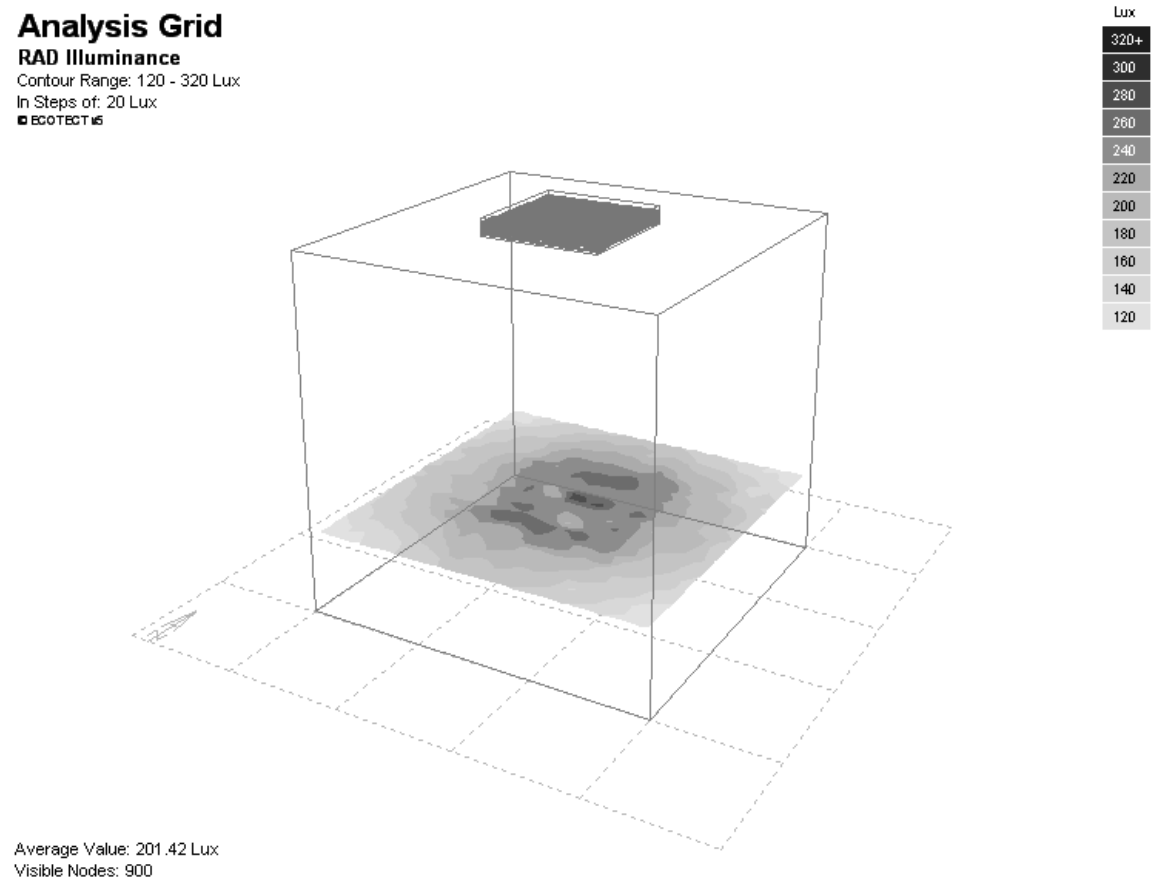

Fig. 1. Simulation model in a black box [11]

The VT of a glass block was obtained from the ratio of the illumination levels transmitted through each glass block to the illumination level captured by a light sensor in the center of black box without glass block. Sky illuminance set up for all simulations is 9897 lux. In this condition (normal incidence angle) the VT is maximum. Validation was conducted using VT field measurement results of single and 
multiple-glasses with and without cavities. The correction factor is $12 \%$ higher than simulation results, which is obtained from the deviation value between the simulation results and the field measurement results.

The SHGC values were obtained by comparing the simulated direct solar gains (in $\mathrm{W})$ of each glass block model $\left(\mathrm{Q}_{\mathrm{g} \text {-glassblock }}\right)$ to the one of $3 \mathrm{~mm}$ standard glass $\left(\mathrm{Q}_{\mathrm{g}-3 \mathrm{~mm}}\right)$, which were calculated by Ecotect (2).

$$
S H G C_{\text {glassblock }}=\left(Q_{g-\text { glassblock }} / Q_{g-3 m m}\right) * 0.87
$$

In Ecotect solar heat gain is calculated by Losses and Gains. This facility can analyze heat transfer with admittance method, which works based on cyclic variation concept and is valid under steady state condition. The simulation models were constructed as horizontal fenestration on a roof plane of a zero $U$ and painted black zone. Since the simulation date was set on the hottest day, the results describe the maximum SHGC.

Simulation of heat balance analyzes the quantity of the conductive heat gain $\left(Q_{c}\right)$ and $\mathrm{Q}_{\mathrm{g}}$ transferred through each glass block model and the internal heat gain produced by lamp to subtitute the lack of daylighting levels ( $\left.Q_{\text {lamp}}\right)$. Models were built as $1 \mathrm{~m}^{2}$ fenestration on $3 \mathrm{~m} \times 3 \mathrm{~m} \times 3 \mathrm{~m}$ adiabatic room. The internal heat gain was the heat released by a lamp $\left(\mathrm{Q}_{\text {lamp }}\right)$, which was supplemented to reach the same illuminance level as the illuminance level created by $3 \mathrm{~mm}$ standard glass application. One wattage fluorescent lamp power was assummed to produce 11 lux of illumination level and the $20 \%$ of the energy was released as heat. The total heat gain was compared to that of the $3 \mathrm{~mm}$ glass. In an adiabatic and air-tight room the indirect solar gains, the inter-zonal gains, and the ventilation and infiltration gains are zero.

$\mathrm{Q}_{\mathrm{c}}$ refers to conductive heat gains (in $\mathrm{W}$ ) through a surface area in $\mathrm{m}^{2}(\mathrm{~A})$ due to the air temperature differential (in $\mathrm{K}$ ) between inside $\left(\mathrm{T}_{\mathrm{i}}\right.$ in $\left.{ }^{0} \mathrm{C}\right)$ and outside $\left(\mathrm{T}_{0}\right.$ in $\left.{ }^{0} \mathrm{C}\right)$ the space and the thermal transmittance $(\mathrm{U})$ of the surface (3).

$$
Q_{c}=U *\left(T_{0}-T_{i}\right) * A
$$

Whereas, $\mathrm{Q}_{\mathrm{g}}$ is the solar radiation (in $\mathrm{W}$ ) transmitted through a transparent/translucent surface. It depends on the SHGC of the transparent/translucent surface, the total incident solar radiation on the transparent/translucent surface $\left(\mathrm{E}\right.$ in $\left.\mathrm{W} / \mathrm{m}^{2}\right)$ and the glazing area in $\mathrm{m}^{2}(4)$.

$$
Q_{g}=S H G C * E * A
$$

The last step is VT and SHGC laboratory tests to obtain the real LSG. Measurements of the VT referred to the experimental method developed by Wasley and Utzinger [12] with average relative error less than 5\% compared to the manufacturer's data. Artificial lighting (Spotone PAR $80 \mathrm{~W}$ ) replaced the sun to provide weatherindependent measurement with less shading and reflection effects from the surrounding environment. Luxmeter Lutron LX-101 with 5\% of accuracy deviation was used to measure the illuminance level (Fig. 2). The laboratory VT was obtained from 


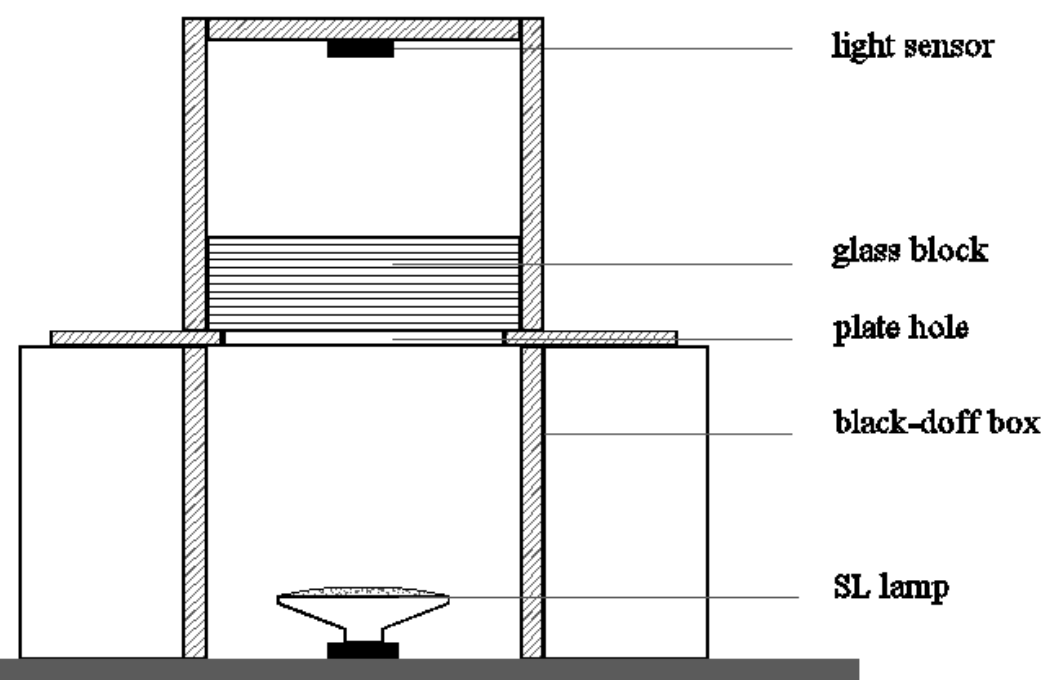

Fig. 2. Schematic apparatus of VT laboratory test
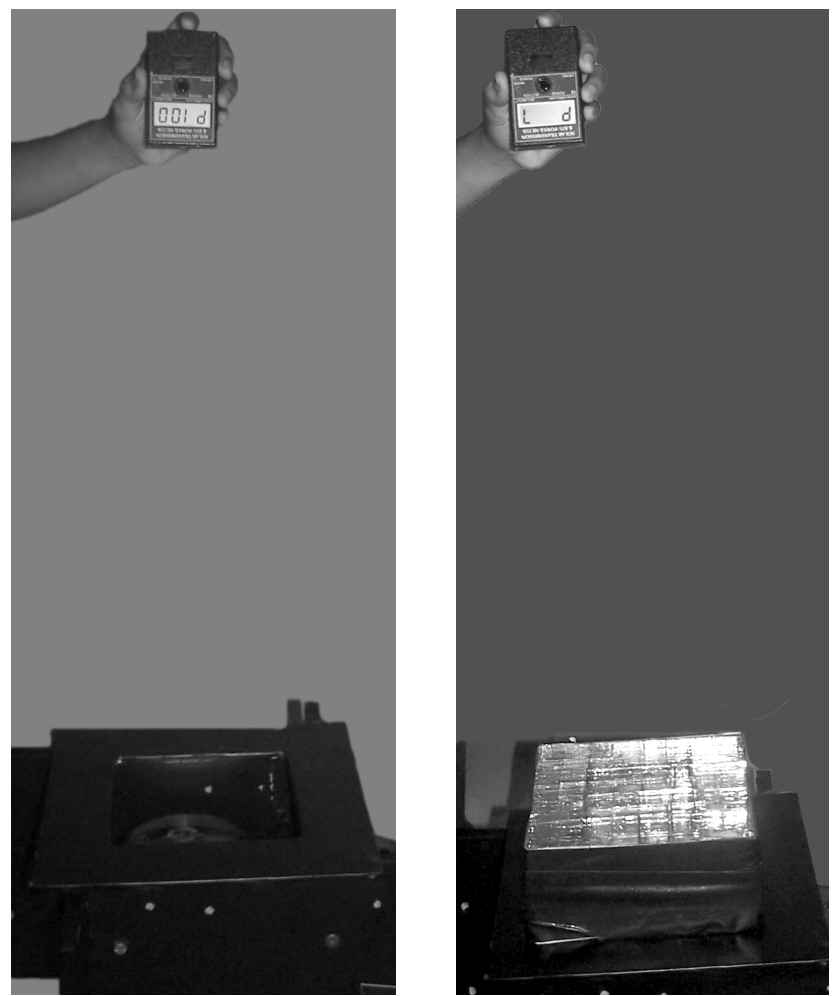

Fig. 3. SHGC measurement using Power meter SP2065: defining the apparatus position (left) and measurement of model 118_13x2_r2_30 (right) 
the ratio of the glass block illuminance level to the illuminance level when no glass was installed. Validation was conducted by comparing the VT measurement of $5 \mathrm{~mm}$ clear glass to the standard VT of $5 \mathrm{~mm}$ clear glass.

SHGC measurements used digital Solar Transmission and Power Meter model SP2065, which has been factory calibrated to a National Institute of Standards and Technology (NIST) traceable thermopile and requires no field adjustment. An infra red heat lamp (PAR38 $150 \mathrm{~W}$ ) was used as heat radiation source. Self-calibration was done by pressing the power mode. When the display was read P100, the power meter is ready to measure the SHGC of the specimen (Fig. 3). The accuracy of self calibration, therefore, depends on the performance of control microprocessor and the apparatus position consistency. Comparative result of the laboratory SHGC of $5 \mathrm{~mm}$ clear glass to the standard value was used to validate the results.

\section{$3 \quad$ Results and Discussions}

When glass block models installed as vertical fenestration of $9 \mathrm{~m}^{3}$ building, lowest indoor temperature was achieved by model with closed cavity (Fig. 4). Closed cavity inside glass block truly functions as thermal insulator. Twelve models with closed cavity, then, were developed with various thickness, cavity width, cavity number, which were selected based on the mechanical strength, the effectiveness of the cavity width and production cost. Table 1 shows that all models have lower $\mathrm{U}$ compared to the standard U established by the Conservation Energy Code 2006. Models with more than $30 \mathrm{~mm}$ in width cavity have relative high SHGC. None raised 1 for the LSG. Only 4 models with $\geq 10 \mathrm{~cm}$ thickness reached low indoor surface temperature $\left(27^{\circ} \mathrm{C}\right)$.
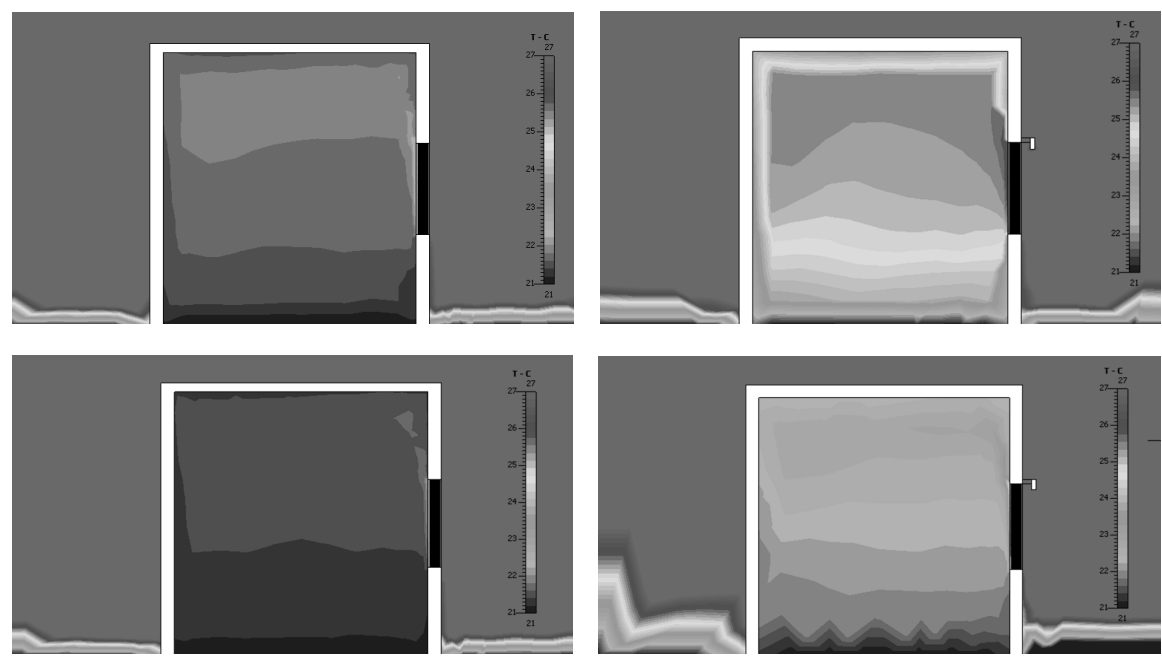

Fig. 4. Temperature profile of application of glass block without cavity (top-left), with open cavity (top-right), with closed cavity (bottom-left), and with open cavity in cooler environment (bottom-right) [11] 
Table 1. Energy Performance of Glass Block Models Based on Analytical and Simulation Approach

\begin{tabular}{|c|c|c|c|c|c|c|}
\hline Model codes ${ }^{\mathrm{a}}$ & $\mathrm{U}\left(\mathrm{W} / \mathrm{m}^{2} \mathrm{~K}\right)$ & $\mathrm{T}_{\mathrm{s} 0}{ }^{\mathrm{b}}\left({ }^{0} \mathrm{C}\right)$ & $\left.\mathrm{T}_{\mathrm{si}}^{\mathrm{c}}{ }^{(0} \mathrm{C}\right)$ & VT & SHGC & LSG \\
\hline $11012 \times 2 \mathrm{r} 130$ & 2.60 & 77.5 & 31.5 & 0.52 & 0.65 & 0.80 \\
\hline 111_12x3_r1_25 & 2.54 & 65.5 & 30 & 0.41 & 0.65 & 0.63 \\
\hline 112_12x2_r1_40 & 3.24 & 78 & 30 & 0.52 & 0.74 & 0.70 \\
\hline $11312 \times 3 \mathrm{rl} 35$ & 3.17 & 67 & 29 & 0.40 & 0.73 & 0.55 \\
\hline $114-14 \times 2 \mathrm{r} 3$ & 2.55 & 75 & 28 & 0.40 & 0.71 & 0.56 \\
\hline 114_13x2_r2_20 & 2.56 & 77.5 & 28 & 0.40 & 0.72 & 0.56 \\
\hline 115_13x3_r2_15 & 2.50 & 67 & 28 & 0.28 & 0.70 & 0.40 \\
\hline 115_12x3_r1_45 & 3.06 & 67 & 28 & 0.40 & 0.71 & 0.56 \\
\hline 118_13x2_r2_30 & 2.60 & 77 & 27 & 0.31 & 0.57 & 0.54 \\
\hline 119_13x3_r2_25 & 2.54 & 67 & 27 & 0.27 & 0.59 & 0.54 \\
\hline 120_14x2_r3_20 & 2.30 & 78 & 27 & 0.31 & 0.67 & 0.46 \\
\hline 121_14x3_r3_15 & 2.28 & 65 & 27 & 0.19 & 0.66 & 0.29 \\
\hline
\end{tabular}

${ }^{a}$ Models are coded using 1A_lBxC_rD_E formula, which means that A is the total layer number, B is the glass layer number per group, $\mathrm{C}$ is the group number, $\mathrm{D}$ is the cavity number, and $\mathrm{E}$ is the thickness of each cavity in $\mathrm{mm}$.

${ }^{\mathrm{b}} \mathrm{T}_{\mathrm{s} 0}=$ outdoor surface temperature

${ }^{\mathrm{c}} \mathrm{T}_{\mathrm{si}}=$ indoor surface temperature

Model 110_12x2_r1_30 was selected to develop, since it has highest LSG, whereas model 118_13x2_r2_30 was selected due to its combination of the lowest SHGC and the medium VT (Fig. 5).
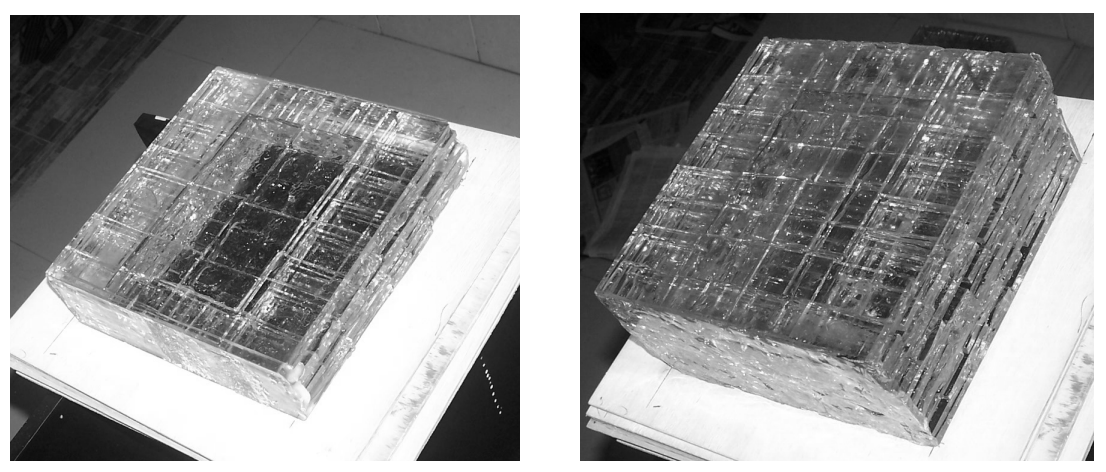

Fig. 5. Prototype of model 110_12x2_r1_30 (left) and model 118_13x2_r2_30 (right)

Application of best models, i.e. 110_12x2_r1_30 and 118_13×2_r2_30 with closed cavity, in $9 \mathrm{~m}^{3}$ building model produced $60 \%$ to $80 \%$ lower heat gain compared to the application of $3 \mathrm{~mm}$ clear glass. Table 2 presents the simulation results of the maximum and the minimum heat gains of the best models compared to $3 \mathrm{~mm}$ clear glass. Glass block with lower SHGC is more efficient than the one with higher VT.

The SHGC and the VT of each prototype were measured 3-5 times. Table 3 shows that laboratory tests of two prototypes resulted in much lower SHGC compared to the 
Table 2. Heat Balance of Best Models

\begin{tabular}{|c|c|c|c|c|c|c|}
\hline Models & $\begin{array}{l}\mathrm{Q}_{\mathrm{c}} \\
(\mathrm{W})\end{array}$ & $\begin{array}{l}\mathrm{Q}_{\mathrm{g}} \\
(\mathrm{W})\end{array}$ & $\begin{array}{c}Q_{c}+Q_{g} \\
(W)\end{array}$ & $\begin{array}{l}\text { Qlamp }_{\text {la }} \\
\text { (W) }\end{array}$ & $\begin{array}{l}\mathrm{Q}_{\text {total }} \\
\text { (W) }\end{array}$ & $\begin{array}{c}\text { Efficiency } \\
(\%)\end{array}$ \\
\hline \multicolumn{7}{|c|}{ Oriented to East } \\
\hline 110_12x2_r1_30 & 142 & 328 & 470 & 5.8 & 476 & $60 \%$ \\
\hline 118_13x2_r2_30 & 142 & 151 & 293 & 6.2 & 299 & $80 \%$ \\
\hline $3 \mathrm{~mm}$ clear glass & 322 & 1007 & 1329 & 0.0 & 1329 & $0 \%$ \\
\hline \multicolumn{7}{|c|}{ Oriented to South } \\
\hline 110_12x2_r1_30 & 142 & 106 & 248 & 5.8 & 254 & $60 \%$ \\
\hline 118_13x2_r2_30 & 142 & 49 & 191 & 6.2 & 197 & $70 \%$ \\
\hline $3 \mathrm{~mm}$ clear glass & 322 & 327 & 649 & 0.0 & 649 & $0 \%$ \\
\hline
\end{tabular}

simulation results. Low standard deviation in laboratory SHGC, i.e. 1.2\%, proved that the results are valid and reliable. Small reductions occurred in the VT with acceptable standard deviation (3.3-4.3\%). The LSG of real glass blocks increases due to the lower laboratory SHGC than the simulated SHGC. The real glass blocks consist of interlayer, which contributes more significant in decreasing the SHGC than in decreasing the VT.

A big difference between the percentage difference of simulated SHGC and laboratory SHGC shows that adding glazing interlayer reduced the SHGC more than adding glazing layer. The lower emissivity of the interlayer (0.8) compared to the clear glass emissivity (0.9-0.95) made the glass block emit less heat to the interior. The less transparent (slight higher RI) interlayer compared to the clear glass might create small (percentage) difference of simulated VT and laboratory VT.

Table 3. Laboratory Test Results of the VT and the SHGC

\begin{tabular}{lccc}
\hline Properties & 110_12x2_r1_30 & 118_13x2_r2_30 & Percentage Difference \\
\hline Laboratory VT & 0.47 & 0.30 & $36 \%$ \\
Simulated VT & 0.52 & 0.31 & $40 \%$ \\
Laboratory SHGC & 0.18 & 0.06 & $67 \%$ \\
Simulated SHGC & 0.65 & 0.57 & $12 \%$ \\
Laboratory LSG & 2.50 & 4.35 & $(-) 74 \%$ \\
Simulated LSG & 0.80 & 0.54 & $32 \%$ \\
\hline
\end{tabular}

The wide discrepancy values of the SHGC were probably caused by the accuracy of the simulation program. In simulated SHGC Ecotect did not calculate the absorption and the back transmission of solar radiation occurring among the glazing layers. Whereas, Radiance proved its accuracy in calculating inter-reflections among glass layers described in the simulated VT.

\section{Conclusions}

Closed cavity with medium width admits optimum visible light and low solar radiation transmitted across the glass block. Cavity width should be no more than $30 \mathrm{~mm}$ to avoid high SHGC. Glass block's thickness is another factor determining the SHGC and the indoor surface temperature. The presence of interlayer (epoxy resin) in laminated glass block reduces the SHGC significantly with small reduction in the VT. 
Contribution of interlayer in reduction of the SHGC depends on the emissivity. Certain combination of closed cavity and interlayer number can help the glass block to raise high energy performance, i.e. LSG. New interlayer with lower emissivity and lower refractive index can effectively create a higher energy performance laminated glass block.

Acknowledgments. Authors are grateful to Directorate General of Higher Education (Dirjen DIKTI), Ministry of National Education for funding this research in the scheme of "National Competitive Grant" (Hibah Bersaing) under the contract no. 055/SP2H/PP/DP2M/IV/2009 on April 6, 2009 and no. 301/SP2H/P/DP2M/IV/2010 on April 12, 2010. Thank is also addressed to Mr. Widijanto (laboratory staff) for preparing the specimens.

\section{References}

1. International Institute of Energy Conservation and USAID. Energy Conservation Building Code 2006. Bureau of Energy Efficiency, New Delhi (2006)

2. Chen, Z., Meng, Q.: Analysis and research on the thermal properties of energy-efficient building glass: a case study on PVB laminated glass. In: Proc. Sixth International Conference for Enhanced Building Operations, Shenzhen (2006)

3. Evoy, M., Southall, R.G.: Validation of a Computational Fluid Dynamics Simulation of a Supply Air Ventilated Window. In: Proc. 20/20 Vision CIBSE/ASHRAE conference, Dublin, Ireland (2000)

4. Gosselin, J.R., Chen, Q.: A dual airflow window for indoor air quality improvement and energy conservation in buildings. HVAC \& R Research 14(3), 359-372 (2008)

5. Powles, R., Curcija, D., Kohler, C.: Solar absorption in thick and multilayer glazings. In: Proc. the World Renewable Energy Congress VII, Cologne (2002)

6. Xaman, J., Alvarez, G., Hinojosa, J., Flores, J.: Conjugate turbulent heat transfer in a square cavity with a solar control coating deposited to a vertical semitransparent wall. Heat and Fluid Flow 30(2), 237-248 (2009)

7. Satwiko, P., Locke, N., Donn, M.: Reproducing the real pressure coefficient using a computational fluid dynamic program: how close is close enough? In: Proc. the 32nd Annual Conference of the Australia and New Zealand Architectural Science Association, Wellington (1998)

8. Mardaljevic, J.: Verification of program accuracy for illuminance modeling: assumptions, methodology and an examination of conflicting findings. Lighting Research \& Technology 36(3), 218-238 (2004)

9. Reinhart, C.F., Andersen, M.: Development and validation of a Radiance model for a translucent panel. Energy and Buildings 38(7), 890-904 (2006)

10. Laouadi, A., Arsenault, C.: Validation of skylight performance Assessment Software. ASHRAE Transactions 112(2), 1-13 (2006)

11. Binarti, F., Istiadji, A.D., Satwiko, P., Iswanto, P.T.: Analytical and Computational Simulation Approaches to Design Low Energy Glass Block (in Ind). Makara seri Teknologi 15(2), 115-122 (2011)

12. Wasley, J.H., Utzinger, M.: Vital Signs 2. Johnson Controls Institute for Environmental Quality in Architecture, School of Architecture and Urban Planning, University of Wisconsin- Milwaukee, Milwaukee (1996) 